Jurnal Health Sains: p-ISSN: 2723-4339 e-ISSN: 2548-1398

Vol. 2, No. 9, September 2021

\title{
POTENSI ANTIOKSIDAN MENGGUNAKAN METODE DPPH EKSTRAK BERAS HITAM (ORYZA SATIVA L INDICA) DAN PENGHAMBATAN TIROSINASE
}

\author{
Bayu Febram Prasetyo ${ }^{1}$, Rini Madyastuti Purwono ${ }^{2}$, Alvin Valgar Novarino ${ }^{3}$ \\ Staff Pengajar Divisi Faramasi Veteriner Departemen Klinik, Reproduksi, dan Patologi, Fakultas \\ Kedokteran Hewan Institut Pertanian Bogor, Jawa Barat, Indonesia ${ }^{1,2}$, Mahasiswa Fakultas \\ Kedokteran ${ }^{3}$ \\ Email: bayupr@apps.ipb.ac.id, rinipurwono@gmail.com, alvin.valgar@gmail.com
}

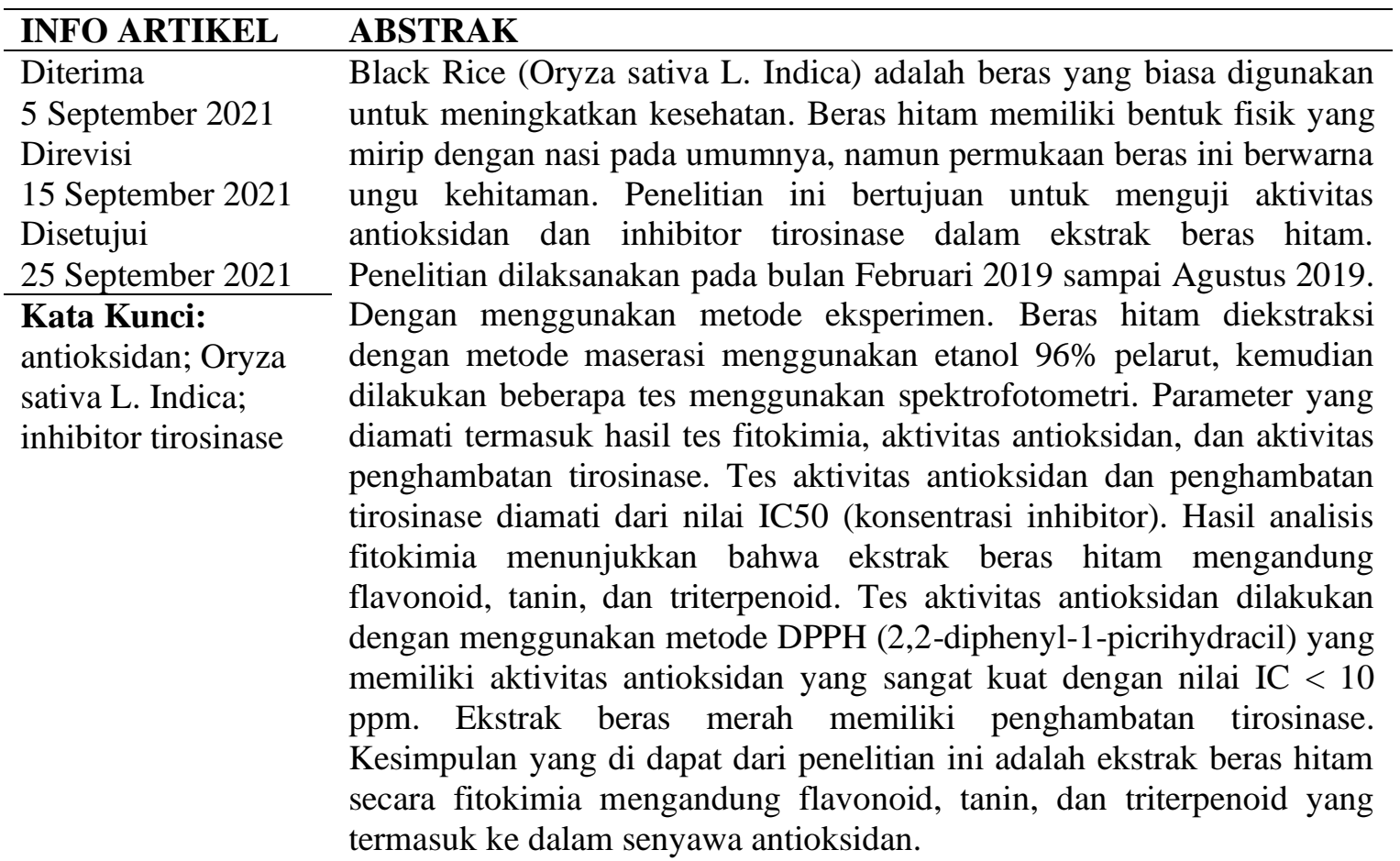

\section{ABSTRACT}

Black Rice (Oryza sativa L. Indica) is a rice commonly used to improve health. Black rice has a physical shape similar to rice in general, but the surface of this rice is blackish purple. The study aimed to test the antioxidant activity and tyrosinase inhibitors in black rice extract. The study was conducted from February 2019 to August 2019. Using experimental methods. Black rice is extracted by the maceration method using $96 \%$ solvent ethanol, then several tests are performed using spectrophotometry. Observed parameters include phytochemical test results, antioxidant activity, and tyrosinase inhibition activity. Tests of antioxidant activity and inhibition of tyrosinase were observed from IC50 (inhibitor concentration) values. The results of phytochemical analysis showed that black rice extract contains flavonoids, tannins, and triterpenoids. The antioxidant activity test is performed using the DPPH

Keywords: (2,2-diphenyl-1-picrihydracil) method which has very strong antioxidant antioxidant activity; activity with an IC value of $<10 \mathrm{ppm}$. Brown rice extract has inhibition Oryza sativa $L$. of tyrosinase. The conclusion that can be from this study is that black

$\begin{array}{ll}\text { How to cite: } & \text { Prasetyo, B. F., Purwono, R. M., \& Novarino, A. V. (2021) Potensi Antioksidan Menggunakan } \\ & \text { Metode DPPH Ekstrak Beras Hitam (Oryza Sativa L Indica) dan Penghambatan Tirosinase. Jurnal } \\ & \text { Health Sains 2(9). https://doi.org/10.46799/jhs.v2i9.281 } \\ \text { E-ISSN: } & \text { 2723-6927 } \\ \text { Published by: } & \text { Ridwan Institute }\end{array}$


Indica; tyrosinase rice extract phytochemicalally contains flavonoids, tannins, and inhibitors triterpenoids that are included in antioxidant compounds.

\section{Pendahuluan}

Paparan sinar matahari berlebih merupakan salah satu penyebab kerusakan pada kulit akibat sinar ultraviolet yang dipancarkan. Kerusakan ersebut atanra lain kerusakan DNA, eritema, mutasi, dan pigmentasi (Layuck et al., 2015). Selain itu, paparan sinar matahari dapat menyebabkan hiperpigmentasi. Hiperpigmentasi adalah kondisi perubahan warna kulit menjadi lebih gelap pada bagian tertentu akibat produksi berlebih melanin (Minerva, 2018). Melanin diproduksi oleh tubuh untuk melindungi dari paparan sinar matahari, semakin intensnya paparan sinar matahari maka produksi melanin akan meningkat. Enzim tirosinase merupakan biokatalis utama dalam biosintesis melanin (Chang, 2009). Proses pembentukan melanin diakibatkan perubahan tirosin oleh tirosinase menjadi DOPA (1-3.4dihydroxyphenylalanine), kemudian dirubah menjadi melanin melalui beberapa tahapan transformasi (Likhitwitayawuid, 2008).

Antioksidan adalah substansi yang mampu mereduksi radikal bebas sehingga dapat mencegah atau mengurangi pembentukan racun secara efisien (Boligon et al., 2014). Antioksidan alami yang dapat diperoleh dari tanaman salah satunya adalah antosianin. Antosianin termasuk senyawa flavonoid, merupakan kelompok terbesar pigmen alami pada tumbuhan yang larut air (Suzery et al., 2010).

Beras hitam merupakan varietas lain dari beras putih yang berasal dari Benua Asia. Beras ini ditemukan dan dikembangkan dari negara China, Jepang, Korea, Thailand, dan Indonesia (Sah \& Kushwaha, 2016). Sejarah China mengenal beras hitam sebagai beras terlarang karena di jaman kekaisaran hanya bangsawan yang boleh mengonsumsi beras hitam. Pemanfaatan beras hitam sebagai makanan pokok dipercaya oleh masyarakat untuk meningkatan kesehatan dan kualitas hidup.

Beras hitam memiliki bentuk fisik yang mirip dengan beras pada umumnya, namun pada permukaanya beras ini berwarna ungu kehitaman. Permukaan hitam pada bulir beras merupakan lapisan pericarp yang menutupi bagian endosperma berwarna putih di dalamnya. Warna beras hitam berasal dari aleuron dan endospermia yang memproduksi flavonoid. Salah satu jenis flavonoid pada beras hitam yaitu antosianin dengan intensitas tinggi sehingga menimbulkan warna ungu pekat hingga hitam (Hernawan \& Meylani, 2016). Selain memiliki antosianin beras hitam memiliki kelebihan lain yakni anti kanker, hipoglikemia, dan antiinflamasi (Suhartatik et al., 2013). Besarnya manfaat beras hitam membuat masyarakat mulai memanfaatkan beras hitam baik untuk dikonsumsi maupun diolah menjadi bahan bermanfaat lainnya seperti bahan kosmetik alami. Kandungan flavonoid pada beras hitam menjadi indikasi bahwa beras hitam memiliki kemampuan antioksidan dan penghambat tirosinase sehingga perlu dilakukan pengujian lebih lanjut dalam keefektivan sebagai sediaan pemutih kulit.

Penelitian ini bertujuan untuk menguji aktivitas antioksidan dan daya penghambatan tirosinase pada ekstrak beras hitam.

Penelitian ini sebagai penelitian pendahuluan yang diharapkan dapat memberikan pengetahuan tentang aktivitas antioksidan dan daya hambat tirosinase pada ekstrak beras hitam. Hasil yang diperoleh dari penelitiaan ini diharapkan dapat digunakan sebagai dasar dalam penelitian selanjutnya. 


\section{Metode Penelitian}

Penelitian dilaksanakan pada bulan Februari 2019 sampai Agustus 2019. Dengan menggunakan metode eksperimen. Pembuatan ekstrak beras hitam dilakukan di Laboratorium Farmasi Veteriner, Departemen Klinik, Reproduksi dan Patologi, Fakultas Kedokteran Hewan, IPB University. Proses evaporasi dilakukan di laboratorium Pusat Antar Universitas, IPB University. Pengujian fitokimia, antioksidan, dan penghambatan tirosinase dilakukan di Pusat Studi Biofarmaka Tropika, IPB University.

Alat yang digunakan dalam penelitian ini adalah timbangan digital, peralatan metode maserasi, evaporator, waterbath, desikator, vortex, microplate, inkubator, ELISA microplate reader, dan alat-alat gelas yang biasa digunakan di laboratorium. Bahan yang digunakan dalam penelitian ini adalah beras hitam (Oryza sativa L. Indica), vitamin $\mathrm{C}$, etanol $70 \%$, asam kojat, reagen uji fitokimia, L-DOPA, L-tyrosinase, dan 2,2Difenil 1- pikrihidrasil (DPPH).

Sampel beras hitam diperoleh dari Sirampog, Kabupaten Brebes. Beras dibersihkan dengan cara dicuci dengan air besih, kemudian ditiriskan sampai beras hampir kering.

Pembuatan ekstrak beras hitam dilakukan dengan metode maserasi. Beras hitam yang telah dihaluskan dimaserasi menggunakan etanol $96 \%$ dengan perbandingan 1:10 dan didiamkan selama 24 jam dan diambil filtratnya. Proses maserasi dilakukan lagi dengan menambahkan etanol 96\% pada beras hitam yang digunakan pada proses maserasi sebelumnya. Proses maserasi ini dilakukan selama 3 kali. Hasil filtrat maserasi kemudian dibawa ke PAU Bioteknologi IPB untuk di evaporasi menjadi ekstrak kental kulit beras hitam. Hasil evaporasi kemudian dibawa ke Pusat Studi Biofarmaka Tropika IPB untuk diuji fitokimia, antioksidan, dan penghambat tirosinase.
Sebanyak 1 g sampel ditambahkan beberapa tetes $\mathrm{NH} 3$ kemudian dihaluskan, selanjutnya ditambahkan $5 \mathrm{~mL} \quad \mathrm{CHCl} 3$ kemudian disaring, selanjutnya filtrat ditambahkan dengan $\mathrm{H} 2 \mathrm{SO} 4$ 2M. Lapisan asam dibagi 3 bagian. Bagian 1 ditambahkan reagen Dragendrof, apabila terjadi perubahan warna menjadi jingga maka menunjukkan positif adanya alkaloid. Bagian 2 ditambahkan reagen Mayer, apabila berwarna putih maka bereaksi positif. Bagian 3 ditambahkan reagen Wagner, apabila berwarna coklat maka bereaksi positif.

Akuades ditambahkan ke dalam beaker glass berisi $5 \mathrm{~g}$ sampel kemudian dipanaskan selama 5 menit dan disaring. Hasil saringan ditambahkan serbuk Mg, HCl:EtOH (1:1), dan amil alkohol. Hasil positif ditandai dengan larutan ekstrak menjadi berwarna jingga.

Akuades ditambahkan ke dalam beaker glass berisi $5 \mathrm{~g}$ sampel kemudian dipanaskan selama 5 menit dan disaring. Hasil saringan ditambahkan 3 tetes $\mathrm{FeCl} 3$ 10\%. Hasil positif ditandai dengan hasil reaksi berwarna hitam kehijauan.

Akuades ditambahkan ke dalam beaker glass berisi $5 \mathrm{~g}$ sampel. Campuran ini kemudian dipanaskan selama 5 menit dan disaring. Hasil saringan kemudian.

Sebanyak $1 \mathrm{~g}$ sampel ditambahkan etOH panas kemudian disaring. Hasil saringan dipanaskan hingga kering kemudian ditambahkan $1 \mathrm{ml}$ dietil eter dan dihomogenkan, kemudian ditambahkan 1 tetes $\mathrm{H} 2 \mathrm{SO} 4$ pekat dan 1 tetes $\mathrm{CH} 3 \mathrm{COOH}$ anhidrat. Hasil positif ditunjukkan dengan triterpenoid berwarna merah/ungu dan positif steroid jika berwarna hijau/biru.

Sebanyak $1 \mathrm{~g}$ sampel ditambahkan $\mathrm{MeOH}$. Campuran ini kemudian dipanaskan dan selanjutnya disaring. Hasil saringan ditambahkan 3 tetes $\mathrm{NaOH}$ 10\%. Apabila berwarna merah maka bereaksi positif.

Pembuatan stok DPPH $125 \mu \mathrm{M}$ dengan cara $2.5 \mathrm{mg}$ DPPH dilarutkan dengan etanol 
dalam labu ukur dan ditera hingga volume 50 $\mathrm{mL}$ labu ukur kemudian dilapisi dengan aluminium foil. Preparasi sampel dan vitamin $\mathrm{C}$ dengan cara masing-masing ditimbang sebanyak $10 \mathrm{mg}$. Sampel dan vitamin C kemudian dilarutkan dengan DMSO sebanyak $1 \mathrm{~mL}$. Campuran kemudian disonikasi hingga larut dan selanjutnya divorteks. Sampel dibuat dengan konsentrasi 50, 100, 150, 200, dan $250 \mathrm{ppm}$. Sampel dan vitamin C dimasukkan sebanyak $100 \mu \mathrm{L}$ ke dalam microplate. Sampel ulangan satu dan dua ditambahkan DPPH sebanyak $100 \mu \mathrm{L}$, untuk kontrol negatif hanya ditambahkan etanol sebanyak $100 \mu \mathrm{L}$. Microplate kemudian di inkubasi pada suhu ruang dalam kondisi gelap selama 30 menit. Setelah diinkubasi, dilakukan pengukuran dengan ELISA microplate reader pada panjang gelombang $517 \mathrm{~nm}$. Penentuan persentase penghambatan dihitung dengan menggunakan rumus:

$\%$ Penghambatan $=$

Absorbansi blanko - Absorbansi sampel $\times 100 \%$

Absorbansi blanko

Menurut (Romansyah et al., 2019), hasil perhitungan dimasukkan ke dalam persamaan regresi dengan konsentrasi sampel sebagai absis (sumbu X) dan nilai persen penghambatan antioksidan sebagai ordinat (sumbu Y). Persamaan regresi linier yang diperoleh dalam bentuk persamaan $\mathrm{y}=\mathrm{a}(\mathrm{x})+$ $\mathrm{b}$ digunakan untuk mencari Inhibition.

Aktivitas penghambatan tirosinase diuji secara in vitro dengan mengacu pada (Batubara et al., 2010). Larutan ekstrak induk dengan konsentrasi $20 \mathrm{mg} / \mathrm{mL}$ dibuat dari 2 mg ekstrak padat yang dilarutkan dalam 0.1 $\mathrm{mL}$ dimetil sulfoksida (DMSO). Konsentrasi ekstrak yang digunakan adalah 31.25-2000 $\mu \mathrm{g} / \mathrm{mL}$ dengan pengenceran larutan induk dalam buffer natrium fosfat $(50 \mathrm{mM}$ dan $\mathrm{pH}$ 6.5). Kontrol positif dalam penelitian ini adalah asam kojat yang diuji pada konsentrasi $7.82-500 \mu \mathrm{g} / \mathrm{mL}$.
Ekstrak dari berbagai konsentrasi sebanyak $70 \mu \mathrm{L}$ dimasukkan ke dalam tiap lubang sumur dalam microplate dan ditambahkan dengan $30 \mu \mathrm{L}$ enzim tirosinase yang berasal dari jamur (Sigma, $333 \mu \mathrm{ml}-1$ ). Pengujian dilakukan dengan tiga kali ulangan. Setelah itu, plate disimpan di dalam ruangan inkubasi yang bertemperatur ( $37 \mathrm{oC}$ ) selama 5 menit. Selanjutnya, substrat (2 mM Ltirosin dan $12 \quad \mathrm{mM} \quad$ L-3,4dihydroxyphenylalanine (L-DOPA) sebanyak $110 \mu \mathrm{L}$ ditambahkan ke dalam tiap-tiap lubang sumur. Plate tersebut kemudian disimpan dalam ruang inkubasi selama 30 menit.

Nilai absorbansi dari tiap sumur kemudian ditentukan menggunakan multiwell reader pada panjang gelombang $492 \mathrm{~nm}$. Selanjutnya, konsentrasi dari masing-masing ekstrak yang dapat menghambat setengah dari aktivitas tirosinase tersebut ditentukan dengan cara membandingkan absorbansi sampel tanpa penambahan ekstrak dengan penambahan ekstrak. Persentase aktivitas penghambatan tirosinase dihitung dengan rumus berikut:

$\%$ Penghambatan $=$

Absorbansi blanko - Absorbansi sampel $\times 100 \%$

Absorbansi blanko

Nilai IC $\neg 50$ diperoleh dari persamaan regresi linier antara \% penghambatan (sumbu y) dan konsenrasi ekstrak (sumbu $\mathrm{x}$ ), persamaan regresi linier dapat dirumuskan sebagai berkut:

$$
\mathrm{Y}=\mathrm{a}+\mathrm{bx}
$$

Keterangan: Y: Variabel dependen

$\mathrm{x}$ : Variabel independent

a: Konstanta

b: Koofisien regresi

Data yang diperoleh dianalisis dengan analisis deskriptif dan menggunakan software Microsoft Excel. 


\section{Hasil dan Pembahasan}

Penapisan fitokimia merupakan salah satu pendekatan dalam penelitian tumbuhan obat untuk mendeteksi senyawa tumbuhan berdasarkan golongan (Fajriah \& Megawati, 2015). Penapisan fitokimia bertujuan untuk menganalisis secara kualitatif berbagai macam kandungan bioaktif tumbuhan atau bagian pada tumbuhan (akar, daun, batang, buah, dan biji) terutama kandungan metabolit sekunder seperti alkaloid, tanin, fenol, minyak atsiri, antrakuinon, flavonoid, saponin, steroid, dan triterpenoid. Uji yang digunakan di antaranya uji flavonoid, alkaloid, tanin, saponin, kuinon, steroid, dan triterpenoid. Hasil uji kualitatif ekstrak beras hitam disajikan dalam Tabel 1.

\section{Tabel 1}

Kandungan fitokimia ekstrak beras hitam (Oryza sativa L. Indica)

\begin{tabular}{cc}
\hline Parameter & Hasil \\
\hline Flavonoid & Positif \\
\hline Alkaloid & Negatif \\
\hline Tanin & Positif \\
\hline Saponin & Negatif \\
\hline Quinon & Negatif \\
\hline Steroid & Negatif \\
\hline Triterpenoid & Positif
\end{tabular}

Keterangan: Positif $=$ Mengandung senyawa

Negatif $=$ Tidak mengandung senyawa

Hasil uji skrining fitokimia menyatakan bahwa ekstrak beras hitam mengadung flavonoid, tanin, dan triterpenoid. Menurut (Alfaridz, 2018) flavonoid merupakan salah satu kelompok polifenol yang diklasifikasikan berdasarkan biokimia dan biosintesisnya. Flavonoid yang terkandung dalam tanaman umumnya dapat berperan sebagai antioksidan, antiinflamasi, antidiabetes, antimikroba dan yang lainnya. Dalam sebuah larutan, flavonoid dapat bekerja sinergis dengan antioksidan lain dan meningkatkan kemampuan antioksidan yang terdapat dalam larutan tersebut (Hidalgo et al., 2010). Warna pada beras hitam ditunjukan oleh pigmen antosianin pada permukaanya (Sah \& Kushwaha, 2016). Antosianin pada beras hitam terdiri atas cyanidine-3-glucoside, peonidin-3-glucoside, cyanidine-3.5glucoside, cyanidine-3-rutinoside (Hou et al., 2013).

Tanin secara umum didefinisikan sebagai senyawa polifenol dengan molekul protein yang cukup kompleks dan berat cukup tinggi yakni lebih dari $1000 \mathrm{mg} / \mathrm{kg}$ asam tanat (satuan tanin). Tanin memiliki aktivitas biologis sebagai antioksidan sehingga tanin yang terkandung dalam ekstrak beras hitam berpengaruh terhadap aktivitas antioksidan (Malangngi et al., 2012). Triterpenoid merupakan senyawa metabolit dari isopentenyl pyrophosphate oligomer. Senyawa ini berfungsi sebagai antiinflamasi dan antikanker. Triterpenoid bekerja menghambat aktivasi NF-KB (nuclear factor kappaB) yang merupakan senyawa protein kompleks untuk meregulasi inflamasi dengan menghambat IKK- $\alpha$ (inhibitory kappa alpha kinase) atau IKK- $\beta$ (inhibitory kappa beta kinase). Inflamasi kronis mampu memicu terjadinya berbagai penyakit sistemik lain, salah satunya kanker. Adanya triterpenoid sebagai inhibitor NF- $\kappa \mathrm{B}$ menjadikan senyawa ini sekaligus berperan sebagai antikanker (Yadav et al., 2010).

\section{A. Aktivitas Antioksidan}

Uji aktivitas antioksidan ekstrak beras hitam dilakukan menggunakan metode 2,2-Difenil-1-pikrihidrasil (DPPH). Parameter yang digunakan untuk interpretasi DPPH adalah nilai IC50 (inhibitor concentration). IC50 merupakan konsentrasi larutan substrat atau sampel yang mampu mereduksi aktivitas DPPH sebesar 50\% (Pontoh et al. 2019). Nilai IC50 berbanding terbalik dengan aktivitas antioksidannya. Semakin kecil nilai IC50 maka aktivitas antioksidan semakin kuat (Zuraida et al., 2017). Metode DPPH menggunakan vitamin $\mathrm{C}$ sebagai kontrol 
positif. Vitamin $\mathrm{C}$ terbukti memiliki aktivitas antioksidan yang mampu menetralisir dan menghilangkan radikal bebas dari polusi lingkungan atau radiasi ultraviolet (Pullar et al., 2017).

\section{Tabel 2}

\section{Hasil Uji Aktivitas Antioksidan}

\begin{tabular}{lc}
\hline \multicolumn{1}{c}{ Sampel } & IC $_{\mathbf{5 0}}$ (ppm) \\
\hline Vitamin C & 2.59 \\
Ekstrak Oryza sativa L. Indica & $<10$ \\
\hline
\end{tabular}

Hasil pengujian menyatakan bahwa vitamin C memiliki nilai IC50 lebih kecil dibandingkan dengan nilai IC50 ekstrak beras hitam. Hal ini menggambarkan bahwa aktivitas antioksidan vitamin $\mathrm{C}$ sebagai kontrol positif lebih besar dibandingkan dengan sampel. Meskipun demikian, ekstrak beras hitam memiliki nilai IC50 jauh di bawah 50 ppm sehingga mempunyai kerja antioksidan yang kuat. Hal ini sesuai dengan pernyataan (Chandra et al., 2019) bahwa suatu senyawa dapat dikatakan memiliki kerja antioksidan kuat ketika memiliki nilai IC50<50 ppm, sedang ketika nilai IC50 berada antara 101-150 ppm, dan lemah ketika nilai IC50>150 ppm. Dalam hal ini sampel ekstrak beras hitam masih memiliki kekuatan antioksidan yang kuat.

Faktor yang mempengaruhi tinggi rendahnya konsentrasi antioksidan di antaranya ialah proses pengekstrakan yang optimal, ditandai dengan rendahnya kadar air yang terkandung dalam ekstrak $(<10 \%)$. Hal ini bergantung pada suhu dan waktu ekstraksi (Yuliantari et al. 2017). Faktor lainnya ialah komposisi tanah, suhu, curah hujan, jenis pelarut, dan radiasi ultra violet (Khoddami et al., 2013).

B. Aktivitas Penghambatan Tirosinase

Pengujian penghambatan tirosinase dilakukan dengan cara in vitro menggunakan substrat L-Tirosin dan L-
DOPA. Uji aktivitas hambatan tirosinase dilakukan untuk mengetahui ada atau tidaknya daya hambat senyawa bioaktif yang terdapat pada ekstrak beras hitam. Uji terhadap penghambatan tirosinase yang digunakan dalam penelitian ini adalah aktivitas diphenolase dan monophenolase.

Asam kojat sebagai kontrol positif memiliki efek penghambatan yang kompetitif pada aktivitas monophenolase dan efek penghambatan pada campuran aktivitas difenolase jamur tirosinase (Muddathir et al., 2017). Hasil pengujian dapat dilihat pada Tabel 3.

\section{Tabel 3}

\section{Hasil Uji Aktivitas Penghambatan} Enzim Tirosinase

\begin{tabular}{lcc}
\hline \multirow{2}{*}{ Sampel } & \multicolumn{2}{c}{ IC50(ppm) } \\
\cline { 2 - 3 } & Diphenolase & Monophenolase \\
\hline Asam kojat & 62.79 & 31.73 \\
Ekstrak Oryza & $>2000$ & $>2000$ \\
sativa L. Indica & & \\
\hline
\end{tabular}

Aktivitas inhibitor tirosinase yang terdapat dalam ekstrak ditentukan oleh nilai IC50 yang menggambarkan konsentrasi ekstrak yang dapat menghambat $50 \%$ aktivitas enzim tirosin. Nilai tersebut dapat diperoleh dari persamaan regresi hasil interpolasi antara konsentrasi ekstrak dengan persen penghambatan difenolase dan monofelase.

Hasil uji menyatakan bahwa IC50 diphenolase dan monophelase dari ekstrak beras hitam adalah >2000 ppm sedangkan nilai IC50 asam kojat sebagai kontrol positif yaitu sebesar 62.79 ppm untuk diphenolase dan 31.73 ppm untuk monophelase. Sampel dikatakan inhibitor aktif jika memiliki nilai IC50 kurang dari $1.000 \mathrm{ppm}$ sedangkan diatas $1.000 \mathrm{ppm}$ maka sampel tersebut tergolong inhibitor tidak aktif. Hasil uji tirosinase ekstrak beras hitam menunjukan bahwa ekstrak beras hitam merupakan inhibitor tidak 
aktif terhadap tirosinase karena memiliki nilai IC50 diatas $2.000 \mathrm{ppm}$.

Metabolit sekunder dalam tanaman dapat menghambat pembentukan melanin pada kulit dengan cara berperan sebagai inhibitor tirosinase. Enzim tirosinase dihambat melalui reaksi L-tirosin menjadi L-DOPA atau disebut dengan penghambatan monofenolase dan menghambat reaksi L-DOPA menjadi dopakuinon atau penghambatan difenolase (Chang, 2009). Dikarenakan hasil pengujian IC50 jauh lebih besar dibandingkan dengan nilai ketetapan, maka dapat dikatakan bahwa ekstrak beras hitam tidak memiliki aktivitas yang baik dalam penghambatan tirosinase.

Kemampuan daya penghambatan yang rendah diperoleh dari ekstrak beras hitam disebabkan jenis senyawa bioaktif yang terkandung bereaksi negatif dengan pelarut etanol. Hal ini dapat dibandingkan dengan hasil penelitian (Maharni, 2015) yang menunjukkan bahwa jenis pelarut mempengaruhi kemampuan dari inhibitor tirosinase pada ekstrak beras hitam yang mana dari ketiga pelarut yang digunakan (n-heksana, etil asetat, dan metanol) metanol merupakan pelarut terbaik karena memiliki nilai IC50 yang paling rendah, namun penggunaan metanol sebagai bahan konsumsi manusia sudah dilarang oleh Uni Eropa dan FDA (Food and Drug Administration).

Aktivitas antioksidan yang kuat dan lemahnya aktivitas penghambatan tirosinase dapat menggambarkan bahwa aktivitas antioksidan yang baik tidak selalu dipengaruhi oleh peran terhadap penghambatan tirosinase yang baik. Tirosinase mempunyai peran penting dalam biokatalisis melanin sebagai pemberi warna cokelat pada kulit sekaligus pelindung dari sinar ultra violet (UV) (Hoogduijn et al., 2004). Oleh karena itu ketika nilai penghambatan tirosinase dalam sampel rendah, maka akan menyebabkan kadar melanin yang tinggi, dengan kata lain suatu sampel kurang efektif untuk dijadikan pemutih kulit.

\section{Kesimpulan}

Ekstrak beras hitam secara fitokimia mengandung flavonoid, tanin, dan triterpenoid yang termasuk ke dalam senyawa antioksidan. Aktivitas antioksidan yang ditunjukkan termasuk ke dalam efek antioksidan kuat sedangkan aktivitas penghambatan tirosinase menunjukan efek yang kurang baik sehingga dalam hal ini sediaan ekstrak beras hitam kurang ampuh dijadikan sebagai pemutih kulit.

\section{BIBLIOGRAFI}

Alfaridz, A. (2018). Review Jurnal: Klasifikasi Dan Aktivitas Farmakologi Dari Senyawa Aktif Flavonoid. Farmaka, 16(3). Google Scholar

Batubara, I., Darusman, L. K., Mitsunaga, T., Rahminiwati, M., \& Djauhari, E. (2010). Potency Of Indonesian Medicinal Plants As Tyrosinase Inhibitor And Antioxidant Agent. Journal Of Biological Sciences, 10(2), 138-144. Google Scholar

Boligon, A. A., Machado, M. M., \& Athayde, M. L. (2014). Technical Evaluation Of Antioxidant Activity. Med Chem, 4(7), 517-522. Google Scholar

Chandra, B., Sari, R. P., Misfadhila, S., Azizah, Z., \& Asra, R. (2019). Skrining Fitokimia Dan Aktivitas Antioksidan Ekstrak Metanol Daun Kemangi (Ocimum Tenuiflorum L.) Dengan Metode Dpph (1, 1-Difenil-2Pikrilhidrazil). Journal Of Pharmaceutical And Sciences, 2(2), 1-8. Google Scholar 

dan Penghambatan Tirosinase

Chang, T.-S. (2009). An Updated Review Of Tyrosinase Inhibitors. International Journal Of Molecular Sciences, 10(6), 2440-2475. Google Scholar

Fajriah, S., \& Megawati, M. (2015). Penapisan Fitokimia Dan Uji Toksisitas Dari Daun Myristica Fatua Houtt. Chimica Et Natura Acta, 3(3). Google Scholar

Hernawan, E., \& Meylani, V. (2016). Analisis Karakteristik Fisikokimia Beras Putih, Beras Merah, Dan Beras Hitam (Oryza Sativa L., Oryza Nivara Dan Oryza Sativa L. Indica). Jurnal Kesehatan Bakti Tunas Husada: Jurnal Ilmu-Ilmu Keperawatan, Analis Kesehatan Dan Farmasi, 15(1), 79-91. Google Scholar

Hidalgo, M., Sánchez-Moreno, C., \& De Pascual-Teresa, S. (2010). FlavonoidFlavonoid Interaction And Its Effect On Their Antioxidant Activity. Food Chemistry, 121(3), 691-696. Google Scholar

Hoogduijn, M. J., Cemeli, E., Ross, K., Anderson, D., Thody, A. J., \& Wood, J. M. (2004). Melanin Protects Melanocytes And Keratinocytes Against H2o2-Induced Dna Strand Breaks Through Its Ability To Bind Ca2+. Experimental Cell Research, 294(1), 60-67. Google Scholar

Hou, Z., Qin, P., Zhang, Y., Cui, S., \& Ren, G. (2013). Identification Of Anthocyanins Isolated From Black Rice (Oryza Sativa L.) And Their Degradation Kinetics. Food Research International, 50(2), 691-697. Google Scholar

Khoddami, A., Wilkes, M. A., \& Roberts, T. H. (2013). Techniques For Analysis Of Plant Phenolic Compounds. Molecules, 18(2), 2328-2375. Google Scholar

Layuck, A. R. P., Lintong, P. M., \& Loho, L. L. (2015). Pengaruh Pemberian Air Perasan Jeruk Nipis (Citrus Aurantifolia) Terhadap Jumlah Pigmen
Melanin Kulit Mencit (Mus Musculus) Yang Dipaparkan Sinar Matahari. Ebiomedik, 3(1). Google Scholar

Likhitwitayawuid, K. (2008). Stilbenes With Tyrosinase Inhibitory Activity. Current Science, 44-52. Google Scholar

Maharni, M. (2015). Potensi Beras Putih (Oryza Sativa), Beras Hitam (O. Sativa L. Indica), Dan Beras Merah (O. Nivara) Sebagai Antioksidan Dan Inhibitor Tirosinase. Google Scholar

Malangngi, L., Sangi, M., \& Paendong, J. (2012). Penentuan Kandungan Tanin Dan Uji Aktivitas Antioksidan Ekstrak Biji Buah Alpukat (Persea Americana Mill.). Jurnal Mipa, 1(1), 5-10. Google Scholar

Minerva, P. (2018). Hiperpigmentasi. Google Scholar

Muddathir, A. M., Yamauchi, K., Batubara, I., Mohieldin, E. A. M., \& Mitsunaga, T. (2017). Anti-Tyrosinase, Total Phenolic Content And Antioxidant Activity Of Selected Sudanese Medicinal Plants. South African Journal Of Botany, 109, 9-15. Google Scholar

Pullar, J. M., Carr, A. C., \& Vissers, M. (2017). The Roles Of Vitamin C In Skin Health. Nutrients, 9(8), 866. Google Scholar

Romansyah, Wijaya, A., \& Yanuriati, A. (2019). Karakteristik Fisik, Kimia Dan Sensoris Dodol Ketan Dengan Substitusi Tepung Beras Hitam (Oryza Sativa L.) Dan Penambahan Bubur Pisang. Sriwijaya University. Google Scholar

Sah, S. K., \& Kushwaha, U. K. S. (2016). Book Review: Black Rice: Research, History, And Development. Adv Plants Agric Res, 5(1), 165. Google Scholar

Suhartatik, N., Karyantina, M., Mustofa, A., Cahyanto, M. N., Raharjo, S., \& Rahayu, E. S. (2013). Stabilitas Ekstrak Antosianin Beras Ketan (Oryza Sativa 
Bayu Febram Prasetyo, Rini Madyastuti Purwono, Alvin Valgar Novarino

Var. Glutinosa) Hitam Selama Proses Pemanasan Dan Penyimpanan. Agritech, 33(4), 384-390. Google Scholar

Suzery, M., Lestari, S., \& Cahyono, B. (2010). Penentuan Total Antosianin Dari Kelopak Bunga Rosela (Hibiscus Sabdariffa L) Dengan Metode Maserasi Dan Sokshletasi. Jurnal Sains Dan Matematika, 18(1), 1-6. Google Scholar
Toxins, 2(10), 2428-2466. Google Scholar

Zuraida, Z., Sulistiyani, S., Sajuthi, D., \& Suparto, I. H. (2017). Fenol, Flavonoid, Dan Aktivitas Antioksidan Pada Ekstrak Kulit Batang Pulai (Alstonia Scholaris R. Br). Jurnal Penelitian Hasil Hutan, 35(3), 211-219. Google Scholar

Yadav, V. R., Prasad, S., Sung, B., Kannappan, R., \& Aggarwal, B. B. (2010). Targeting Inflammatory

Pathways By Triterpenoids For Prevention And Treatment Of Cancer.

\section{Copyright holder:}

Bayu Febram Prasetyo, Rini Madyastuti Purwono, Alvin Valgar Novarino (2021)

First publication right:

Jurnal Health Sains

This article is licensed under:

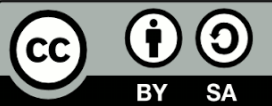

